\title{
PELATIHAN BUDIDAYA BSF MELALUI PEMANFAATAN KULIT BUAH KOPI
}

\author{
Tuti Karyani, Endah Djuwendah, dan Kuswarini Kusno \\ Staf Pengajar Program Studi Agribisnis Fakultas Pertanian Universitas Padjadjaran \\ E-mail: tutikaryani23@gmail.com
}

\begin{abstract}
ABSTRAK. Pengembangan sektor perkebunan, khususnya kopi secara tidak langsung akan menambah volume limbah kopi yang dihasilkan. Pemanfaatan limbah kulit tanduk buah kopi saat ini belum maksimal. Koperasi Produsen Kopi Margamulya, Kecamatan Pangalengan sudah memanfaatkan limbah kulit buah kopi sebagai kompos dan cascara. Kegiatan pengabdian kepada masyarakat ini merupakan PKM berbasis riset dan terintegasi dengan KKN. Metode yang digunakan berupa pemberdayaan partisipatif melalui rangkaian kegiatan yang terdiri dari observasi partisipatif, penyuluhan, pelatihan dan pendampingan. Sasaran PKMadalahpetanikopi pada KPK Margamulya. Kegiatan PKM yangdilaksanakanberupa peningkatan kemampuan petani dalam budidaya BSF dengan memanfaatkan limbah kulit buah kopi sebagai pakan ternak alternatif melalui serangkaian kegiatan penyuluhan dan pelatihan budidaya BSF. Hasilevaluasi menunjukkanbahwapetani meningkat pengetahuannya mengenai materiyang disampaikan dan antusiasmengikutipelatihan sampai selesai. Guna keberlanjutan kegiatan ini maka diperlukan pendampingan.
\end{abstract}

Kata kunci: Limbah Kopi; BSF; Pakan Ternak Alternatif

\section{BSF CULTIVATION TRAINING THROUGH THE USE OF COFFEE HORN SKIN}

\begin{abstract}
The development of the plantation sector, especially coffee will indirectly increase the volume of coffee waste produced. Utilization of coffee fruit skin waste is currently not maximized. Margamulya Coffee Producer's Cooperative (CPC), Pangalengan District has utilized coffee horn skin waste as compost and cascara. This Community Service Activity (CSA) is a research-based service and is integrated with Student Work Program (SWP). The method used in the form of participatory empowerment through a series of activities consisting of participatory observation, counseling, training and mentoring. The target of CSA is coffee farmers in the Margamulya CPC. CSA activities carried out in the form of increasing the ability of farmers in the cultivation of BSF by utilizing coffee fruit skin waste as alternative animal feed through a series of extension activities and BSF cultivation training. The evaluation results showed that farmers increased their knowledge of the material presented and were enthusiastic about attending the training until completion. For the sustainability of this activity assistance is needed.
\end{abstract}

Key words: Coffee waste; BSF; alternative animal feed

\section{PENDAHULUAN}

Salah satu komoditas perkebunan yang memiliki nilai ekonomis tinggi dan berperan sebagai sumber devisa negara adalah kopi. Indonesia menduduki peringkat keempat sebagai negara penghasil kopi terbesar di dunia setelah Brazil, Vietnam, dan Kolombia (ICO, 2017). Selain itu, kopi juga merupakan sumber penghasilan bagi kurang lebih satu setengah juta jiwa petani kopi di Indonesia (Rahardjo, 2012).

Direktorat Jenderal Perkebunan tahun 2016 menyebutkan bahwa Jawa Barat menempati peringkat ke 11 sebagai produsen kopi terbesar di Indonesia (Djuwendah et al, 2018), di mana luas lahannya mencapai $32.558 \mathrm{Ha}$ dan menghasilkan sebanyak 16.645 ton kopi. Produsen kopi terbesar di Jawa Barat adalah Kabupaten Bandung, dengan salah satu sentranya berada di Kecamatan Pangalengan yang memproduksi kopi mencapai 14.680 ton pada tahun 2016 (BPS, 2017).

Petani menghasilkan buah kopi berupa cery kemudian diproses menjadi bentuk greenbean (berasan), roasting bean (kopi sangray) dan ground coffee (kopi bubuk). Perubahan bentuk ini memberikan nilai tambah (Karyani, 2018). Selain produk utamanya, banyaknya jumlah produksi kopi maka akan meninggalkan banyak limbah saat melakukan pengolahan. Limbah buah kopi biasanya berupa kulit kopi dengan proporsi 40-45\% (Simanihuruk et al, 2010). Padahal, kulit kopi memiliki kandungan $6,67 \%$ protein kasar, 18,28\% serat kasar, 1,0\% lemak, 0,21\% kalsium dan 0,03\% fosfor (Khalil, 2016).

Pemanfaatan limbah kopi saat ini belum maksimal, padahal dengan adanya pengembangan sektor perkebunan, khususnya kopi secara tidak langsung akan menambah volume limbah kopi yang dihasilkan. Koperasi Produsen Kopi (KPK) Margamulya merupakan salah satu koperasi produsen kopi di Kecamatan Pangalengan yang sudah memanfaatkan limbah kulit kopi sebagai kompos dan cascara yaitu teh yang terbuat dari kulit ceri kopi yang telah diolah sedemikian rupa kemudian dikeringkan.

Saat ini ada cara lain yang dapat dilakukan untuk memanfaatkan kulit buah kopi, yaitu dengan menjadikannya sebagai media budidaya BSF (Black Soldier Fly) yaitu serangga yang aktif 
mengkonsumsi bahan organik seperti sayur dan buah-buahan, sampah dapur, limbah ikan, bungkil kelapa sawit, sampah pasar dan kotoran hewan dan manusia (Fahmi, 2015). Larva Black Soldier Fly bermanfaat dalam biokonversi pada sampah organik dan mampu menurunkan polusi lingkungan yang disebabkan oleh kotoran hewan dan manusia dalam waktu singkat (Wangko, 2014).

Selain mampu mereduksi sampah, tahap akhir larva BSF yang biasa disebut prepuna dapat dipanen sendiri dan menghasilkan nilai tambah yang tinggi (Diener et al., 2011). Larva BSF sendiri mengandung protein yang cukup tinggi berkisar 40-50\% dengan kandungan lemak 29-32\% (Bosch et al., 2014) sehingga dapat digunakan sebagai pakan ternak dan ikan pengganti tepung ikan. Nutrisi larva BSF juga dapat dijadikan bahan baku pakan alami mengingat hingga saat ini Indonesia masih mengimpor pakan ikan meskipun telah mengalami penurunan sebsar $15.56 \%$ (BPS, 2012).

Berdasarkan kondisi tersebut, Kegiatan Pengabdian Pada Masyarakat (PPM) ini bertujuan untuk memberi pengetahuan tentang berbagai manfaat dari BSF dan mengadakan pelatihan budidaya BSF dengan memanfaatkan limbah kulit buah kopi agar lebih menguntungkan baik secara ekonomi, sosial, maupun lingkungan.

\section{METODE}

Kegiatan PPM ini dilaksanakan di Koperasi Produsen Kopi (KPK) Margamulya, Kecamatan Pangalengan, Kabupaten Bandung. Metode yang digunakan dalam kegiatan ini adalah pemberdayaan partisipatif berupa penyuluhan, pelatihan, dan pendampingan dengan melibatkan peran serta mitra secara aktif mulai dari perencanaan, pelaksanaan, monitoring, dan evaluasi.

Pelatihan dilakukan secara berkelompok dengan metode ceramah, diskusi, dan demontrasi. Inovasi dalam kegiatan PPM ini berupa pengetahuan dan melatih keterampilan petani dalam melakukan aktivitas budidaya BSF dengan memanfaatkan limbah kulit buah kopi sehingga dapat mengetahui dan merasakan manfaatnya baik secara ekonomi, sosial, maupun lingkungan.

Indikator keberhasilan program PPM ini dapat dilihat dari perubahan pengetahuan dan keterampilan petani dalam memanfaatkan limbah biji kopi sebagai media budidaya BSF.

\section{HASIL DAN PEMBAHASAN}

Koperasi Produsen Kopi (KPK) Margamulya merupakan lembaga yang memegang peran penting dalam agribisnis kopi di Desa Margamulya,
Kecamatan Pangalengan, Kabupaten Bandung. Pemanfaatkan limbah kulit buah kopi yang masih belum maksimal mendasari dilaksanakannya kegiatan PPM yang berlangsung di sekitar KPK Margamulya.

Hasil kegiatan menunjukkan peserta pelatihan sangat antusias mengikuti tahapan pelatihan sehingga tingkat pengetahuan peserta mengenai budidaya BSF meningkat $100 \%$. Demikian juga pengetahuan mengenai analisis ekonominya, sehingga mendorong minat untuk mencoba budidaya BSF dengan memanfaatkan limbah kulit tanduk buah kopi yang selama ini hanya diketahui bisa dijadikan kompos dan cascara (teh kopi). Untuk keterampilannya dicoba dibuat kelompok karena keterbatasan alat dan bahan yang kami sediakan dengan harapan bisa digulirkan berikutnya ke anggota. Dari hasil monev menunjukkan peserta meningkat keterampilannya dalam pembesaran larva BSF hanya masih ada sedikit kendala dalam pembibitannya.

Berikut ini dibahas mengenai hal yang dicapai berdasarkan tahapan dalam metode kegiatan budidaya BSF:

\section{Morfologi dan Siklus Hidup BSF}

Larva BSF (Hermetia illucens) dewasa berbentuk pipih dan memiliki panjang antara 15$20 \mathrm{~mm}$. Tubuh jantan warna abdomennya lebih coklat sedangkan betina seluruhnya berwarna biruhitam. Lalat BSF dewasa tidak memiliki mulut yang fungsional karena aktivitas lalat dewasa hanya untuk kawin dan bereproduksi sepanjang hidupnya. Kebutuhan nutrisi pada lalat dewasa tergantung pada kandungan lemak yang disimpan saat masa pupa. Apabila simpanan lemak habis maka lalat tersebut akan mati (Makkar et al., 2014). Dilihat dari jenis kelaminnya, Tomberlin et al (2009) menyebutkan bahwa umumnya lalat jantan memiliki daya tahan lebih lama daripada lalat betina.

Siklus hidup BSF secara alami yaitu lalat betina akan meletakkan telurnya pada sumber makanan seperti sampah organik. Telur lalat BSF akan menetas setelah 3-6 hari. Hasil penelitian yang dilakukan oleh Monita et al (2017) menunjukkan bahwa telur menetas mencapai lebih dari $95 \%$ pada hari ke-3 setelah peletakan telur di media kultur dan memasuki fase aktif makan. Selama fase makan, larva akan terus mengalami pertumbuhan panjang, lebar, dan bobot hingga fase pupa. Fase larva ini berlangsung 12-13 hari dan dijadikan landasan untuk mengelompokkan larva BSF sebagai agen biokonversi berbagai limbah organik karena hidupnya berperan sebagai dekomposer (Fahmi, 2015).

Tahap berikutnya yaitu prepupa yang merupakan fase tidak aktif makan lagi berlangsung selama 6 hari. Tahap ini dicirikan dengan adanya perubahan warna tubuh pada larva yaitu kekuningan, coklat kekuningan, coklat muda sampai coklat gelap. 
Selanjutnya fase prepupa bermetamofosis menjadi fase pupa yang berlangsung selama 6 hari yang dicirikan dengan adanya perubahan warna tubuh yaitu coklat gelap sampai hitam legam. Selain itu, pergerakan tubuh prepupa yang melambat berangsurangsurtidak bergerak (pasif) dengan tekstur kulitpupa lebih keras, berkerut serta bobot tubuh lebih ringan. Larva menyimpan banyak lemak sebagai cadangan makanan sampai menjadi serangga dewasa. Prepupa dapat dengan mudah dipanen dan digunakan sebagai bahan pakan berharga dalam budidaya perikanan, peternakan ayam dan hewan ternak lainnya.

Salah satu faktor yang memiliki peranan dalam siklus hidup BSF adalah suhu. Suhu yang hangat atau di atas $30^{\circ} \mathrm{C}$ akan menyebabkan lalat dewasa menjadi aktif dan lebih produktif. Pemeliharaan larva dan pupa BSF pada suhu $27^{\circ} \mathrm{C}$ berkembang empat hari lebih lambat dibandingkan dengan suhu $30^{\circ} \mathrm{C}$ (Tomberlin et al. 2009). Suhu juga berpengaruh terhadap masa inkubasi telur di mana suhu yang hangat memicu telur untuk menetas lebih cepat dibandingkan dengan suhu yang dingin.

\section{Faktor Yang Mempengaruhi Aktivitas Kawin BSF}

Aktivitas kawin yang dilakukan BSF umumnya terjadi pukul 8.30 dan puncaknya pada 10.00 di lokasi yang penuh tanaman ketika suhu lingkungan mencapai $27^{\circ} \mathrm{C}$. Lalat betina hanya kawin dan bertelur sekali selama masa hidupnya. Saat melakukan aktivitas kawin, lalat jantan akan memberikan sinyal ke lalat betina untuk datang ke lokasi yang telah ditentukan oleh pejantan. Perkawinan BSF terjadi di tanah dengan posisi jantan dan betina berlawanan (saling membelakangi) atau di daerah yang penuh dengan vegetasi. Intensitas cahaya dan suhu sangat berpengaruh terhadap kesuksesan aktivitas kawin lalat BSF (Gobbi et al. 2013). Umumnya lalat dewasa membutuhkan penerangan yang tinggi tetapi masih di bawah intensitas sinar matahari. Minimal intensitas cahaya yang dibutuhkan untuk aktivitas kawin adalah $70 \mu \mathrm{mol} \mathrm{m} \mathrm{m}^{-2} \mathrm{~s}^{-1}$, sedangkan puncak aktivitas kawin terjadi pada kondisi penerangan 100 $\mu \mathrm{mol} \mathrm{m} \mathrm{m}^{-2} \mathrm{~s}^{-1}$ atau lebih dari $200 \mu \mathrm{mol} \mathrm{m} \mathrm{m}^{-2} \mathrm{~s}^{-1}$ hingga $500 \mu \mathrm{mol} \mathrm{m}^{-2} \mathrm{~s}^{-1}$ (Sheppard et al. 2002).

\section{Teknik Budidaya Larva BSF}

Lalat BSF ditemukan hampir di seluruh wilayah, namun jumlah terbanyak ditemukan di daerah yang berpenduduk sedikit. Proses budidaya lalat BSF di wilayah yang berpenduduk padat dapat dilakukan dengan sistem tertutup menggunakan kandang. Sedangkan untuk wilayah yang berpenduduk sedikit dapat dilakukan dengan sistem terbuka menggunakan tong-tong besi yang ditutup penutup tong diselingi dengan kawat, fiber dan bambu.
Adapun tahap budidaya lalat BSF menggunakan limbah kulit buah kopi (mengadopsi dari Jayanthi et al., 2017) sebagai berikut :

a. Penetasan telur

- Media campuran pur ayam, susu bubuk curah, dan air di dalam container

- Kelembaban media 60\%-90\%

- Larva berada di dalam container penetasan hingga umur 5-DOL

- Setelah 1 minggu, akan didapat larva muda di dalam container

- Dilakukan pengontrolan 3 kali sehari yaitu pagi hari pukul $09.00 \mathrm{WIB}$, siang hari pukul 12.00 WIB dan sore hari pukul 17.00 WIB.

- Dijaga kebersihan kandang agar telur dan larva BSF terhindar dari serangan predator

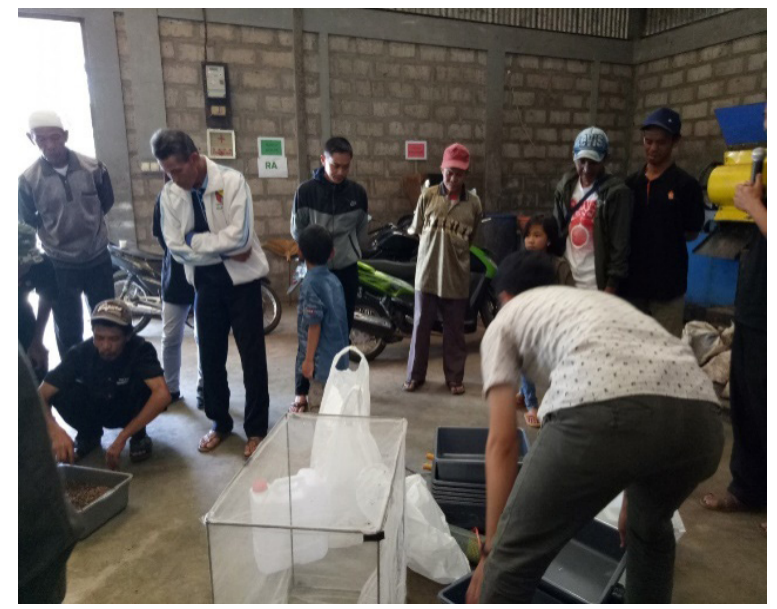

Gambar 1. Pembuatan Media Pembiakan BSF

b. Pembesaran Larva

- Larva umur 5-DOL dipindahkan ke media sampah organik (limbah kulit buah kopi)

- Tambahkan air untuk menjaga kelembaban media $60 \%-90 \%$

- Tambahan limbah kulit buah kopi 3 kg untuk $1 \mathrm{~kg}$ larva (3:1)

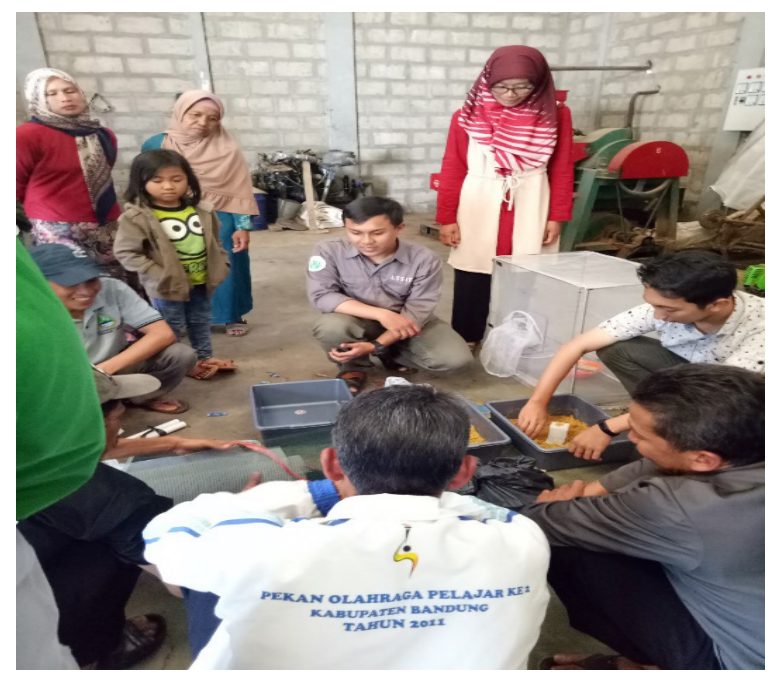

Gambar 2. Pemindahan Larva ke Media Limbah Kulit Buah Kopi 
c. Pemisahan Prepura

- Larva berumur 2-3 minggu semenjak dipindahkan ke media dan berwarna agak gelap

- Dipisahkan menggunakan metode saringan atau metode migrasi

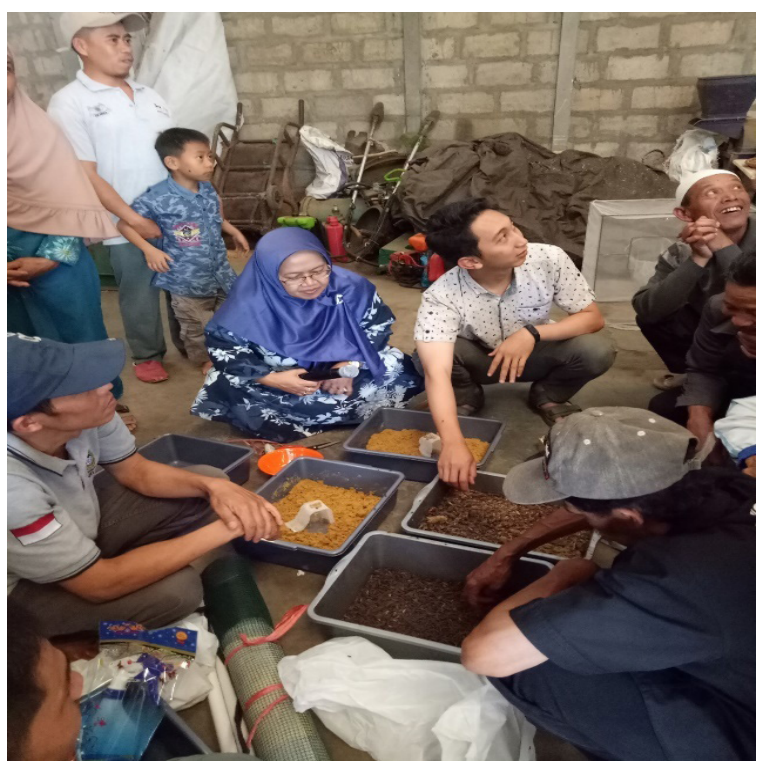

Gambar 3. Pemisahan Prepupa

d. Pupa dan Serangga Dewasa

- Prepupa dibiarkan 3-7 hari hingga tidak bergerak dan warna menghitam

- Simpan di wadah tertutup dan tempat gelap

- Setelah 1-2 minggu, serangga dewasa akan keluar dari pupa,

Cara pemberian BSF kepada ternak dapat dilakukan dengan dua cara :

a. Dalam bentuk fresh, untuk ikan dalam bentuk Larva umur sd 12 hari, untuk ternak pada fase prepupa atau pupa

b. Dalam bentuk olahan tepung.

\section{Kandungan Nutrisi Larva BSF}

Persentase kandungan nutrisi larva BSF secara umum dapat dilihat pada Tabel 1. Kandungan protein pada larva ini cukup tinggi, yaitu 44,26\% dengan kandungan lemak mencapai 29,65\%. Nilai asam amino, asam lemak dan mineral yang terkandung di dalam larva juga tidak kalah dengan sumber-sumber protein lainnya, sehingga larva BSF merupakan bahan baku ideal yang dapat digunakan sebagai pakan ternak (Fahmi et al. 2007).

\section{Keuntungan Larva BSF Sebagai Pakan Ternak}

Pemanfaatan larva BSF memiliki beberapa keuntungan apabila diaplikasikan sebagai pakan ternak. Larva BSF mampu mengurai limbah organik secara efektif karena termasuk dalam golongan detrivora yaitu orgasme pemakan hwan dan tumbuhan yang telah mengalami pembusukan serta tidak menimbulkan bau menyengat selama proses penguraian limbah organik sehingga dapat diproduksi di rumah atau pemukiman (Wardhana, 2016). Larva BSF mampu mengurangi produksi limbah hingga 58\% dan menurunkan konsentrasi populasi nitrogen di kandang (Myers et al., 2008). Sedangkan Zakova dan Barkovcova (2013) menyebutkan bahwa larva BSF telah mampu mengurai sampah tanaman hingga $66,53 \%$.

Keuntungan lain dari larva BSF adalah aman untuk kesehatan manusia karena bukan merupakan vektor suatu penyakit sehingga masih jarang dijumpai pada pemukiman khususnya yang padat penduduk. Menurut Lalander et al. (2015) larva BSF mampu menurunkan daya tahan hidup virus, di mana hasil pengamatan terhadap konsentrasi virus yang diinokulasikan pada sampah organik selama 14 hari menunjukkan bahwa virus yang paling peka terhadap aktivitas larva adalah golongan eneterovirus. Faktor yang diduga mempengaruhi penurunan konsentrasi

Tabel 1. Presentase Kandungan Nutrisi Larva BSF

\begin{tabular}{|c|c|c|c|c|c|c|c|}
\hline Proksimat & $(\%)$ & Asam Amino & $(\%)$ & Asam Lemak & $(\%)$ & Mineral & $(\%)$ \\
\hline Air & 2,38 & Serin & 6,35 & Linoleat & 0,70 & $\mathrm{Mn}$ & $0,05 \mathrm{mg} / \mathrm{g}$ \\
\hline Protein & 44,26 & Glisin & 3,80 & Linolenat & 2,24 & $\mathrm{Zn}$ & 0,09 \\
\hline \multirow[t]{15}{*}{ Lemak } & 29,65 & Histidin & 3,37 & Saturated & $20,00 \mathrm{mg} / \mathrm{g}$ & $\mathrm{Fe}$ & 0,68 \\
\hline & & Arginin & 12,95 & Monomer & 8,71 & $\mathrm{Cu}$ & 0,01 \\
\hline & & Treonim & 3,16 & & & $\mathrm{P}$ & 0,13 \\
\hline & & Alanin & 25,68 & & & $\mathrm{Ca}$ & 55,65 \\
\hline & & Prolin & 16,94 & & & $\mathrm{Mg}$ & 3,50 \\
\hline & & Tirosin & 4,15 & & & $\mathrm{Na}$ & 13,71 \\
\hline & & Valin & 3,87 & & & $\mathrm{~K}$ & 10,00 \\
\hline & & Sistin & 2,05 & & & & \\
\hline & & Isoleusin & 5,42 & & & & \\
\hline & & Leusin & 4,76 & & & & \\
\hline & & Lisin & 10,65 & & & & \\
\hline & & Taurin & 17,53 & & & & \\
\hline & & Sistein & 2,05 & & & & \\
\hline & & NH3 & 4,33 & & & & \\
\hline & & Ornitina & 0,51 & & & & \\
\hline
\end{tabular}


virus di antaranya aktivitas larva, adsorbsi ke dalam partikel dan terjadinya mekanisme inaktivasi amoniak.

Analisis Ekonomi Budidaya BSF, dapat dilihat pada tabel 2

\section{Total Biaya Produksi}

Total biaya produksi yang dikeluarkan dalam usaha produksi BSF dalam satu tahun

Total Biaya Produksi

$=$ Biaya Tetap + Biaya Tidak Tetap

$=\mathrm{Rp} 120.000+\mathrm{Rp} 18.950 .000$

$=\mathrm{Rp} 19.070 .000$

\section{Total Pendapatan PerTahun}

Total pendapatan per tahun

$=$ Total produksi BSF $(\mathrm{kg}) \times$ nilai jual BSF $(\mathrm{Rp})$

$=(20 \mathrm{~kg} /$ hari $\times \mathrm{Rp} 7.000) \times 85 \%$ x (365 hari)

$=\mathrm{Rp} 43.435 .000$

\section{Rugi Laba}

Nilai keuntungan yang diperoleh dalam usaha produksi BSF dapat dihitung dengan rumus berikut ini:

Keuntungan (Rp)

$=$ Total Pendapatan $(\mathrm{Rp})-$ Biaya Produksi $(\mathrm{Rp})$

$=\mathrm{Rp} 43.435 .000-\mathrm{Rp} 19.070 .000$

$=\mathrm{Rp} 24.365 .000$

\section{BEP (Break Even Point) dalam unit}

Keterangan :

$\begin{array}{ll}\mathrm{BEP} & =\text { Break Even Point } \\ \mathrm{FC} & =\text { Fixed Cost } \\ \mathrm{VC} & =\text { Variabel Cost } \\ \mathrm{P} & =\text { Price per unit } \\ \mathrm{S} & =\text { Sales Volume }\end{array}$

Biaya Tetap dan BiayaVariabel (biaya tidak tetap) Perkg

Biaya Tetap per kg

=Biaya Tetap/Kapasitas Produksi

$=120.000 / 6.205=\mathrm{Rp} 19 / \mathrm{Kg}$

BiayaTidak Tetap / Kapasitas Produksi

$=18.950 .000 / 6.205$

$=\mathrm{Rp} 3.054 / \mathrm{Kg}$

BEP Dalam Kg

=Biaya Tetap / (Harga Jual/Kg - Biaya Variabel/

$\mathrm{Kg})$

$=120.000 /(\operatorname{Rp} 7.000-\operatorname{Rp} 3054)$

$=30,42 \mathrm{Kg}$

BEP Dalam Rupiah

Biaya Tetap/1-(Biaya Tidak Tetap/ Penjualan)

$=\mathrm{Rp} \mathrm{120.000/1-(18.950.000/43.435.000)}$

$=\mathrm{Rp} 212.766$

\section{Keterangan:}

Titik impas dalam kg adalah $30,42 \mathrm{~kg}$. Artinya di angka tersebut tidak untung dan tidak rugi.

Titik impas dalam rupiah adalah Rp 212.766

\section{Revenue Cost Ratio (R/C)}

$\mathrm{R} / \mathrm{C}=$ Penerimaan $(\mathrm{Rp}) /$ Total Biaya Produksi (Rp)

$=\operatorname{Rp} 43.435 .000 / \mathrm{Rp} 19.070 .000$

$=2,27$

Nilai R/C 2,27 artinya setiap Rp 100 biaya yang dikeluarkan menghasilkan penerimaan sebesar Rp. 227. Hal ini sesuai dengan kriteria $\mathrm{R} / \mathrm{C}$ lebih dari 1 artinya bahwa usaha tersebut menguntungkan dan layak dijalankan.

Tabel 2. Perhitungan Biaya Produksi Budidaya BSF

\begin{tabular}{|c|c|c|c|c|c|c|}
\hline No & Uraian & Jumlah & Harga Satuan (Rp) & Nilai (Rp) & $\begin{array}{l}\text { Nilai Ekonomis } \\
\text { (tahunan) }\end{array}$ & Penyusutan \\
\hline \multicolumn{7}{|c|}{ INVESTASI } \\
\hline 1 & Insektarium $2 \mathrm{~m}^{2}$ & 1 unit & 500.000 & 500.000 & 10 & 50.000 \\
\hline 2 & $\begin{array}{l}\text { Biotongbak semen dan } \\
\text { bangunan }\end{array}$ & 1 unit & 500.000 & 500.000 & 10 & 50.000 \\
\hline \multirow[t]{2}{*}{3} & Timbangan digital & 1 unit & 100.000 & 100.000 & 5 & 20.000 \\
\hline & Total Investasi & & & 1.100 .000 & & 120.000 \\
\hline \multicolumn{7}{|c|}{ Biaya Operasional Per Tahun } \\
\hline \multicolumn{7}{|c|}{ Biaya Tetap } \\
\hline 1 & Penyusutan Investasi & 1 unit & 120.000 & 120.000 & & \\
\hline 2 & Tenaga Kerja & & & & & \\
\hline 3 & Total Biaya Tetap & & & 120.000 & & \\
\hline \multicolumn{7}{|c|}{ Biaya Variabel } \\
\hline 1 & Listrik dan Air & 12 bulan & 25.000 & 300.000 & & \\
\hline 2 & BBM & 12 bulan & 50.000 & 600.000 & & \\
\hline 3 & Tenaga Kerja & 12 bulan & 1.500 .000 & 18.000 .000 & & \\
\hline \multirow[t]{3}{*}{4} & Ayakan & 1 unit & 50.000 & 50.000 & & \\
\hline & Total Biaya Variabel & & & 18.950 .000 & & \\
\hline & Total Biaya Produksi & & & 19.070 .000 & & \\
\hline
\end{tabular}




\section{SIMPULAN}

Hasil pelatihan menunjukkan bahwa pesertapelatihan meningkat pengetahuan dan keterampilannya dalam berbudidaya BSF, karena sampai saat pelatihan dilakukan, pemanfaatannya baru dijadikan kompos dan cascara. Peserta juga baru mengetahui bahwa larva BSF dapat pula dijadikan pakan ternak dan ikan terutama lele yang mengandung protein tinggi (40-50\%). Selanjutnya bila diolah larva BSF menjadi tepung BSF juga mengandung senyawa antibiotik dan antiviral yang baik bagi kesehatan ternak. Dengan adanya pemanfaatan BSF sebagai sumber protein alternatif dan mudah diproduksi di lingkungan tropis ini, maka akan mampu mengurangi biaya produksi untuk pupuk organik kopi, pakan ayam dan ikan lele. Oleh karena itu disarankan ke depannya selain untuk memenuhi kebutuhan petani sendiri perlu adanya pengolahan larva BSF lebih lanjut untuk menjadi tepung yang kemudian diperkuat jejaring untuk pemasarannya melalui koperasi.

\section{UCAPAN TERIMAKASIH}

Pada kesempatan ini Tim PPM mengucapkan terimakasih kepada DRPMI Unpad yang telah menyelenggarakan dan memberikan Hibah internal Unpad untuk kegiatan PKM sejalan dengan penelitian yang sedang berlangsung di lokasi penelitian sehingga kemanfaatan penelitian terasa langsung oleh kelompok sasaran.

\section{DAFTAR PUSTAKA}

Bosch G, Zhang S, Dennis Gabo, Wouter Hh. 2014. Protein Quality Of Insects As Potential Ingredients For Dog And Cat Foods. J Nutr Sci. 3:1-4.

BPS. 2017. Kecamatan Pangalengan Dalam Angka Tahun 2016. Biro Pusat Statistik Kabupaten Bandung

BPS, 2012. Statistik Ekspor Hasil Perikanan Menurut Komoditi, Provinsi Dan Pelabuhan Asal Ekspor. Pusat Data, Statistik, Dan Informasi Sekretariat Jenderal, Kementerian Kelautan Dan Perikanan, Jakarta

Diener, S., M. Nandayure, S. Solano, F. R. Gutiérrez, C. Zurbrügg, K. Tockner, 2011. Biological Treatment Of Municipal Organic Waste Using Black Soldier Fly Larvae. Waste Biomass Valor 2, Pp. 357-363

Djuwendah, Endah, Tuti Karyani, Agriani H Sadeli, dan Kuswarini Kusno. 2018. Agroindustrialisasi Kopi Arabika Java
Preanger Di Desa Margamulya Kecamatan Pangalengan Kabupaten Bandung. Agricore:Jurnal Agribisnis dan Sosial Ekonomi Pertanian, Vol 3, No.1

Fahmi, M.R. 2015. Optimalisasi Proses Biokonversi Dengan Menggunakan Mini-Larva Hermetia Illucens Untuk Memenuhi Kebutuhan Pakan Ikan. Prosiding Seminar Nasional Masyarakat Biodiversitas Indonesia. Maret 2015. Depok, Indonesia. Hal. 139144.

Fahmi MR, Hem S, Subamia Iw. 2007. Potensi Maggot Sebagai Salah Satu Sumber Protein Pakan Ikan. Dalam: Dukungan Teknologi Untuk Meningkatkan Produk Pangan Hewan Dalam Rangka Pemenuhan Gizi Masyarakat. Prosiding Seminar Nasional Hari Pangan Sedunia Xxvii. Bogor (Indonesia): Puslitbangnak. Hlm. 125-130.

Gobbi P, Martínez-Sánchez A, Rojo S. 2013. The Effects Of Larval Diet On Adult Life-History Traits Of The Black Soldier Fly, Hermetia Illucens (Diptera: Stratiomyidae). Eur J Entomol. 110:461-468.

ICO. 2017. Annual Review 2015-2016. International Coffe Organization. London (UK): International Coffe Organization

Jayanthi, Sri, Rita Khairani, Herika, Muhammad A, Dan Rafiqah. 2017. Teknik Budidaya Black Soldier Fly (Hermetia Illucens). Jurnal Jeumpa, Vol 4 No.1

Karyani, 2018. Comparison of Value-Added Analysis of Coffee Processing with Different Market Orientations: (Case Study on Cooperative of Producer Coffee Margamulya). IOP Conf. Series: Earth and Environmental Science 166 (2018) 012047 doi :10.1088/1755$1315 / 166 / 1 / 012047$

Khalil, Muhammad. 2016. Pengaruh Pemberian Limbah Kulit Kopi(Coffeasp.) AmoniasiSebagaiPakan AlternatifTerhadap Pertambahan BobotAyam Broiler. Jurnal Ilmiah Mahasiswapendidikan Biologi,Volume1, Issue1.

Rahardjo, Pudji. 2012. Panduan Budidaya Dan Pengolahan Kopi Arabika Dan Robusta. Jakarta: Penebar Swadaya

Lalander $\mathrm{Ch}$, Fidjeland J, Diener S, Erikson S, Vinneras B. 2015. High Waste-To-Biomass Conversion And Efficient Salmonella Spp Reduction Using Black Soldier Fly For Waste Recycling. Agron Sustain Dev. 35:261-271. 
Makkar Hps, Tran G, Heuze V, Ankreas P. 2014. State Of The Art On Use Of Insects As Animal Feed. Anim Feed Sci Technol. 197:1-33

Monita, Lena, Surjono Hadi Sutjahjo, Akhmad Arif Amin, dan Melta Rini Fahmi. 2017. Pengolahan Sampah Organik Perkotaan Menggunakan Larva Black Soldier Fly (Hermetia Illucens). Jurnal Pengelolaan Sumberdaya Alam Dan Lingkungan Vol. 7 No. 3

Myers Hm, Tomberlin Jk, Lambert Bd, Kattes D. 2008. Development Of Black Soldier Fly (Diptera: Stratiomyidae) Larvae Fed Dairy Manure. Environ Entomol. 37:11-15.

Sheppard Dc, Tomberlin Jk, Joyce Ja, Kiser Bc, Sumner Sm. 2002. Rearing Methods For The Black Soldier Fly (Diptera: Stratiomyidae). J Med Entomol. 39:695698
Simanihuruk, Kiston Dan J. Sirait. 2010. Silase Kulit Buah Kopi Sebagai Pakan Dasar Pada Kambing Boerka Sedang Tumbuh. Disampaikan Pada Seminar Nasional Teknologi Peternakan Dan Veteriner 2010.

Tomberlin Jk, Adler Ph, Myers Hm. 2009. Development Of The Black Soldier Fly (Diptera: Stratiomyidae) In Relation To Temperature. Enviromental Entomol. 38:930-934

Wangko, S. 2014. Hermetia Illucens Aspek Forensik, Kesehatan Dan Ekonomi. Jurnal Biomedik. 6(1): 2329

Wardhana, April Hari. 2016. Black Soldier Fly (Hermetia Illucens) Sebagai Sumber Protein Alternatif Untuk Pakan Ternak. Wartazoa Vol. 26 No. 2

Zakova M, Barkovcova M. 2013. Comparison Of Field And Lab Application Of Hermetia Illucens Larvae. Mendelnet. 2013:798-801. 